\title{
How 'Clean' Must a Cavity Be before Restoration?
}

\author{
E.A.M. Kidd \\ Guy's, King's and St. Thomas' Dental Institute, London, UK
}

\section{Key Words}

Caries removal - Cavity preparation - Stepwise excavation

\begin{abstract}
The metabolic activity in dental plaque, the biofilm at the tooth surface, is the driving force behind any loss of mineral from the tooth or cavity surface. The symptoms of the process (the lesion) reflect this activity and can be modified by altering the biofilm, most conveniently by disturbing it by brushing with a fluoride-containing toothpaste. The role of operative dentistry in caries management is to restore the integrity of the tooth surface so that the patient can clean. Thus, the question, 'how clean must a cavity be before restoration?' may be irrelevant. There is little evidence that infected dentine must be removed prior to sealing the tooth. Leaving infected dentine does not seem to result in caries progression, pulpitis or pulp death. However, some of the bacteria survive. What is their fate and if they are not damaging, why is this?
\end{abstract}

Copyright @ 2004 S. Karger AG, Basel

\section{Caries the Process, Caries the Lesion}

The disease dental caries is a dynamic process taking place in dental plaque, the microbial deposit (biofilm) on the tooth surface, which results in a disturbance of the equilibrium between tooth substance and the overlying biofilm. Over time, there may be a net loss of mineral, leading to dissolution of the dental hard tissues and possibly a carious lesion that can be seen [Baelum and Fejerskov, 2003].

In this definition of the caries process, it is the metabolic activity in the biofilm that is the all-important driving force. The demineralization of the enamel and dentine beneath may be seen as a reflection of the dynamic events taking place in the biofilm. The implication of this definition is that the symptoms of the process (the lesion) can be modified by alteration of the biofilm; for instance, the lesion can be modified by regular disturbance of the plaque with a brush and a fluoride-containing toothpaste, the fluoride controlling the rate of lesion progression [ten Cate and Featherstone, 1996].

However, at an advanced stage of caries, sometimes a hole (cavity) in a tooth retains the biofilm and careful brushing cannot remove it. Now operative dentistry has a role to play in caries management to restore the integrity of the tooth so that the patient can clean effectively; but once the enamel is cavitated, the dentine becomes demineralized and infected and now the essential question is: what is driving the caries process? Is it the biofilm at

\begin{tabular}{|c|c|c|}
\hline KARGER & $\begin{array}{l}\text { (c) } 2004 \text { S. Karger AG, Basel } \\
0008-6568 / 04 / 0383-0305 \$ 21.00 / 0\end{array}$ & $\begin{array}{l}\text { Prof. E.A.M. Kidd } \\
\text { Floor 25, Guy's Tower }\end{array}$ \\
\hline $\begin{array}{l}\text { Fax + } 41613061234 \\
\text { E-Mail karger@karger.ch }\end{array}$ & Accessible online at: & $\begin{array}{l}\text { London Bridge, SE1 9RT (UK) } \\
\text { Tel. +44 } 2071881573 \text {, Fax +44 } 2071881583\end{array}$ \\
\hline
\end{tabular}


the cavity surface or the infected dentine within the cavity, or both? If it is only the biofilm that drives the caries process, the question, "how "clean" must a cavity be before restoration?' becomes an irrelevance because what matters is sealing the hole in the tooth so that the biofilm can be removed. And yet, the concept of removing infected, demineralized tissue and its replacement by a filling material has spawned a profession, a public and political paymasters who consider that the removal of infected tissue and filling teeth is an essential management of dental caries.

The discussion as to how much tissue must be removed in order to arrest the caries process is not new. In 1859 , John Tomes [1859] wrote, 'it is better that a layer of discoloured dentine should be allowed to remain for the protection of the pulp rather than run the risk of sacrificing the tooth', but in 1908, G.V. Black [1908] disagreed claiming '... it will often be a question of whether or not the pulp will be exposed when all decayed dentine overlaying it is removed ... it is better to expose the pulp of a tooth than to leave it covered only with softened dentine'.

The following discussion will look for evidence to confirm or refute the current practice of cleaning infected tissue out of the cavity prior to placing a restoration. This review of evidence must be preceded by a brief description of caries pathology.

\section{Pulpo-Dentinal Reactions in Response to Caries}

The shape of the enamel lesion is governed by the activity of the bacteria in the overlying biofilm and the orientation of the enamel crystals. The corresponding pulpo-dentinal reactions are similarly influenced by the biofilm with transmission of the stimulus through the enamel being in the direction of the prisms [Thylstrup and Qvist, 1986]. The implication of this is that when acid production ceases at the surface, due to regular disturbance or removal of the biofilm, lesion progression arrests [Bjørndal, 2002]. The demineralized enamel and dentine remain as scars in the tissue. In non-cavitated enamel lesions, the level of bacterial invasion is very low, if present at all. But once the demineralized enamel crumbles and a cavity forms, the biofilm will form in the hole and the dentine becomes infected. Once the biofilm is directly on the dentine, the lesion spreads laterally along the enamel-dentine junction at the edges of the cavity, as well as back through the sound, undermined enamel.

In these deep lesions, there may be large variations and changes within the lesion environment. The central part of the lesion may be cavitated, open and accessible to plaque removal, by chewing and cleaning. In this area, the lesion may progress slowly. However, peripheral parts of the same cavity may still be protected by undermined enamel with heavy plaque accumulation. In these areas, the lesion may progress more rapidly. Thus, it is possible to have slowly and rapidly progressing parts within the same lesion. It is also possible that an entire lesion is rapidly or slowly progressing and the responses of the pulpdentine complex to these two speeds of progression vary. As Massler [1967] pointed out a long time ago, it is essential to differentiate active from arrested lesions if one is to make any sense of the biological reactions.

In slowly progressing lesions, increased mineralization of the dentine beneath the enamel lesion is normal. Formation of highly mineralized peritubular dentine corresponding to the affected dentinal tubules reduces the diameter of the tubules. Furthermore, tertiary dentine forms at the pulpal end of the affected tubules (reactionary dentine). The more active the lesion, the more irregular the structure of this dentine. Together, these processes serve to protect the pulp against exogenous destructive stimuli [Bjørndal and Mjör, 2001].

In rapidly progressing lesions, there may be destruction of the odontoblasts and a lack of formation of tertiary dentine. Now the pulpal tissue will react to the transmission of microbial products through a permeable dentine. There will be inflammatory changes in the pulp leading to either reversible or irreversible pulpitis, sometimes associated with sensitivity or pain. Even though the odontoblasts have been destroyed, new odontoblast-like cells may differentiate from the pulp to form tertiary dentine (reparative dentine) if the cariogenic environment is removed or altered [Bjørndal and Mjör, 2001].

It can be seen from the preceding discussion that the lesion entirely reflects the activity in the biofilm, so it is hardly surprising that modifying the biofilm will modify the lesion. How should this understanding of caries pathology influence the operative dentist?

\section{Root Caries}

Root caries lesions, accessible to cleaning, are of particular relevance to this discussion. The dentine in such lesions is infected at a relatively early stage in lesion progression [Nyvad and Fejerskov, 1990]. Despite this, active lesions can be converted to inactive lesions over a period of months by regular cleaning and fluoride application [Nyvad and Fejerskov, 1986]. Thus, in these lesions, 
Table 1. Chronological overview of studies placing sealants over carious dentine

\begin{tabular}{|c|c|c|c|c|c|}
\hline Study & Treatment & Period & Control & $\begin{array}{l}\text { Indication of } \\
\text { caries activity }\end{array}$ & Result and conclusion \\
\hline Jeronimus et al. [1975] & $\begin{array}{l}\text { occlusal lesions of varying } \\
\text { depths on bitewing } \\
\text { etching, sealant }(n=33) \\
\text { etching, sealant }(n=33) \\
\text { etching, sealant }(n=30) \\
\text { etching, sealant }(n=25)\end{array}$ & $\begin{array}{l}10 \text { min } \\
2 \text { weeks } \\
3 \text { weeks } \\
4 \text { weeks }\end{array}$ & & $\begin{array}{l}\text { gross observation of } \\
\text { carious dentine } \\
\text { micro-organisms } \\
\text { (\% positive cultures) }\end{array}$ & $\begin{array}{l}\text { many sealants lost; where sealant was intact, } \\
\text { dentine became dry, dark, leathery; decrease } \\
\text { in micro-organisms in shallow lesions, but } \\
\text { persist in deeper lesions }\end{array}$ \\
\hline Handelman et al. [1976] & etching, sealant $(n=60)$ & $0-2$ years & $\begin{array}{l}\text { untreated } \\
(\mathrm{n}=29)\end{array}$ & $\begin{array}{l}\text { clinical observation, } \\
\text { radiography, } \\
\text { micro-organisms }\end{array}$ & $\begin{array}{l}\text { no increase in radiographic lesion depth; } \\
\text { large reduction of micro-organisms by com- } \\
\text { parison to controls, increased with time }\end{array}$ \\
\hline Going et al. [1978] & etching, sealant $(n=46)$ & 5 years & $\begin{array}{l}\text { untreated } \\
(\mathrm{n}=21)\end{array}$ & $\begin{array}{l}\text { clinical observation, } \\
\text { micro-organisms }\end{array}$ & $\begin{array}{l}\text { sealed teeth caries arrested; on re-entry either } \\
\text { sterile or large reduction in micro-organisms } \\
\text { in comparison to controls, but Streptoccocus } \\
\text { mutans and lactobacilli survived }\end{array}$ \\
\hline $\begin{array}{l}\text { Mertz-Fairhurst et al. } \\
\text { [1979a] }\end{array}$ & $\begin{array}{l}\text { occlusal lesions at } \\
\text { DEJ on X-ray; } \\
\text { etching, sealant }(n=4)\end{array}$ & $6-12$ months & $\begin{array}{l}\text { untreated } \\
(\mathrm{n}=4)\end{array}$ & $\begin{array}{l}\text { lesion depth } \\
\text { measurements, } \\
\text { micro-organisms }\end{array}$ & $\begin{array}{l}\text { no increase in lesion depth in test; control } \\
\text { lesions increased in depth; absence of micro- } \\
\text { organisms in test sealed teeth }\end{array}$ \\
\hline $\begin{array}{l}\text { Mertz-Fairhurst et al. } \\
\text { [1979b] }\end{array}$ & $\begin{array}{l}\text { occlusal lesions at } \\
\text { DEJ on X-ray; } \\
\text { etching, sealant }(n=4)\end{array}$ & $6-12$ months & $\begin{array}{l}\text { untreated } \\
(\mathrm{n}=6)\end{array}$ & $\begin{array}{l}\text { clinical observations, } \\
\text { radiographs }\end{array}$ & $\begin{array}{l}\text { under sealant dentine powdery, dry, white } \\
\text { with hard, glassy, smooth dentine beneath, } \\
\text { control dentine spongy, soft, yellow; sealed } \\
\text { teeth - no or small increase in depth; control } \\
\text { - increase in depth }\end{array}$ \\
\hline $\begin{array}{l}\text { Jensen and Handelman } \\
\text { [1980] }\end{array}$ & etching, sealant $(n=106)$ & 0-12 months & $\begin{array}{l}\text { unsealed, } \\
\text { unsealed and } \\
\text { etched }\end{array}$ & micro-organisms & $\begin{array}{l}\text { etching alone reduced micro-organisms by } \\
75 \% \text {; in sealed teeth, bacterial counts } \\
\text { reduced with time }\end{array}$ \\
\hline Handelman et al. [1981] & etching, sealant $(\mathrm{n}=108)$ & $2-5$ years & $\begin{array}{l}\text { contralateral } \\
\text { routine } \\
\text { amalgam }\end{array}$ & $\begin{array}{l}\text { radiographic lesion } \\
\text { depth }\end{array}$ & $\begin{array}{l}\text { decrease in lesion depth provided sealant } \\
\text { intact }\end{array}$ \\
\hline $\begin{array}{l}\text { Mertz-Fairhurst et al. } \\
\text { [1986] }\end{array}$ & etching, sealant $(n=14)$ & $1-17$ months & $\begin{array}{l}\text { unsealed } \\
(\mathrm{n}=14)\end{array}$ & $\begin{array}{l}\text { direct lesion depth } \\
\text { measurements and } \\
\text { radiographs; } \\
\text { micro-organisms }\end{array}$ & $\begin{array}{l}\text { unsealed lesions got deeper but sealed lesions } \\
\text { did not; all but I sealed lesion, no micro- } \\
\text { organisms }\end{array}$ \\
\hline Weerheijm et al. [1992] & $\begin{array}{l}\text { teeth already etched } \\
\text { and sealed but occlusal } \\
\text { radiolucency in } \\
\text { dentine }(n=30)\end{array}$ & & & $\begin{array}{l}\text { micro-organisms: } \\
\text { total colony forming } \\
\text { units lactobacilli, } \\
\text { mutans streptococci, } \\
\text { non-mutans strepto- } \\
\text { cocci; clinical obser- } \\
\text { vation of dentine }\end{array}$ & $\begin{array}{l}\text { cariogenic micro-organisms found in } 50 \% \text { of } \\
\text { teeth despite sealant; dentine soft, moist, } \\
\text { dark (not leathery, dry) }\end{array}$ \\
\hline
\end{tabular}

the operative dentist has no need to cut away the infected dentine in order to arrest the lesion. Subsequently, the arrested root caries lesion is only superficially colonized [Beighton et al., 1993] presumably because the soft, infected dentine has been brushed away.

Does this mean that it is not necessary to remove infected dentine when preparing coronal cavities to receive fillings? Once the restoration is in place, there is no chance for the patient to brush the infected material away. What is the fate of these micro-organisms, entombed by the restorative dentist? Do these lesions remain active or are they arrested?

\section{Fissure Sealant Studies}

Table 1 gives a chronological overview of studies investigating the consequences of placing sealants over carious dentine. All studies, with the exception of Weerheijm et al. [1992], were prospective and in many there were unsealed, control, lesions. Caries activity was assessed in a number of ways including clinical observation, lesion depth measurement, radiographic lesion depth measurement and microbiological sampling. Observation periods varied from 2 weeks to 5 years. 
The disparity of methodologies militates against a systematic review of the studies, but some uniform themes emerge. Sealed lesions appeared to arrest both clinically and radiographically. Investigations of the fate of the sealed bacteria showed a decrease in micro-organisms with time or their complete elimination. There was no pulpitis reported in sealed teeth. On the other hand, lesions progressed where sealants were lost and in unsealed, control teeth.

The study of Weerheijm et al. [1992] is an interesting outlier. This work was a retrospective examination of sealed teeth where radiographs showed radiolucency in dentine beneath a sealant that was clinically intact. This methodology precluded microbiological sampling before the sealant was placed, which is unfortunate because there can be no comparison of microbial counts before and after sealing. Nevertheless, it is worrying that cariogenic microorganisms were found in $50 \%$ of the teeth and the dentine was often soft and moist, rather than leathery or dry. This would seem to indicate active lesions. The microbiological examination in this work was more detailed than in many other studies examining for lactobacilli, mutans streptococci and non-mutans streptococci. Since there was no preoperative sample, it is impossible to know whether sealing had changed the numbers or the distribution of the microflora.

\section{Classical Caries Excavation}

The operative tradition is to remove softened dentine in order to eliminate infected tissue. This approach assumes that both the biofilm and the micro-organisms within the carious dentine drive the caries process. In fact, it is not possible to eliminate all the micro-organisms because a few will remain even if all soft dentine is removed [Lager et al., 2003].

At the enamel-dentine junction, some schools teach that the area should be stain-free as well as hard, but a few bacteria remain whatever approach is adopted and thus it seems logical to leave stain in this area as a more conservative approach [Kidd et al., 1996].

Over the pulpal surface, contemporary teaching recommends that carious dentine that is 'firm and leathery' should be left where its removal might expose the pulp [Hilton and Summitt, 2000]. A calcium hydroxide liner is placed over the demineralized area of dentine and this medicament has been shown to significantly reduce the number of remaining bacteria [Leung et al., 1980]. This procedure is called indirect pulp capping. Vigorous exca- vation is positively contraindicated, but the student will find that one teacher's definition of 'firm and leathery' is another's 'rather soft' interpretation.

The subjective clinical assessment of carious dentine led Fusayama [1988] to develop a caries dye (acid red in propylene glycol) to differentiate clinically 'infected' from 'affected' dentine. He reported that the more superficial zone of infected dentine was an irreversibly damaged, bacterially infected layer that would never remineralize. The deepest affected dentine was shown to harden as a result of remineralization [Eidelman et al., 1965]. Fusayama's group suggested the dye staining front coincided with the bacterial invasion of the dentine.

However, several studies have reported that the dye does not discretely discriminate the bacterially infected from softened affected tissues [Anderson et al., 1985; Boston and Graver, 1989; Kidd et al., 1993]. Consequently, its injudicious use may lead to over-preparation of the tissues, encouraging excess removal at the enamel-dentine junction [Kidd et al., 1993] as well as unnecessary removal of dentine over the pulpal surface [Yip et al., 1994].

Soft dentine is usually wet but sometimes, particularly when an old restoration has been removed, the dentine may appear crumbly and dry. This dry dentine has been shown to be minimally infected [Kidd et al., 1995] and it may represent residual caries that a previous dentist left during cavity preparation. This may indicate that there is no need to remove soft, wet dentine. The process may be arrestable by simply sealing it in place.

\section{Stepwise Excavation}

Stepwise excavation, described by Bodecker [1939], differs from the classical excavation of carious lesions described above. Only part of the soft, dentine caries is removed at the first visit during the acute phase of caries progression. The cavity is restored and re-opened after a period of weeks. Further excavation is now carried out prior to a definitive restoration. The objective of the exercise is to arrest lesion progression and allow the formation of tertiary dentine before final excavation, making pulpal exposure less likely.

This procedure has been investigated scientifically for more than 30 years. These studies have involved baseline investigations of carious dentine and then a re-analysis after a period of sealing it in the tooth. This work is important evidence of the consequences of sealing infected dentine into teeth. 
Table 2. Chronological overview of stepwise excavation studies

\begin{tabular}{|c|c|c|c|c|c|c|}
\hline Study & $\begin{array}{l}\text { Toothtype, } \\
\text { lesion depth }\end{array}$ & Treatment & Control & $\begin{array}{l}\text { Time to } \\
\text { re-entry }\end{array}$ & $\begin{array}{l}\text { Indication of carious } \\
\text { activity }\end{array}$ & Result and conclusion \\
\hline $\begin{array}{l}\text { Law and Lewis } \\
\text { [1961] }\end{array}$ & $\begin{array}{l}\text { deciduous and } \\
\text { permanent, } \\
\text { deep lesions }\end{array}$ & $\begin{array}{l}\text { access to caries then } \mathrm{Ca}(\mathrm{OH})_{2} \\
+\mathrm{H}_{2} \mathrm{O} \text { on dentine; amalgam } \\
(\mathrm{n}=66) \text {; re-entry at } 6 \text { months; } \\
\text { excavation completed }(\mathrm{n}=57)\end{array}$ & & $\begin{array}{l}6-24 \\
\text { months }\end{array}$ & $\begin{array}{l}\text { clinical observation; } \\
\text { observation dentine } \\
\text { on re-entry, radio- } \\
\text { graphs }\end{array}$ & $\begin{array}{l}76 \% \text { clinically (no exposure) } \\
\text { and radiographically (no } \\
\text { pathology) successful }\end{array}$ \\
\hline $\begin{array}{l}\text { Schouboe and } \\
\text { Macdonald } \\
{[1962]}\end{array}$ & $\begin{array}{l}\text { molars with } \\
\text { occlusal caries }\end{array}$ & $\begin{array}{l}\text { access, carious dentine sam- } \\
\text { pled; gold plate over dentine, } \\
\text { then amalgam }(n=17)\end{array}$ & & $\begin{array}{l}69-139 \\
\text { days }\end{array}$ & micro-organisms & $\begin{array}{l}\text { positive cultures in } 14 \text { cases, } \\
\text { on re-entry a different flora }\end{array}$ \\
\hline $\begin{array}{l}\text { King et al. } \\
{[1965]}\end{array}$ & $\begin{array}{l}\text { ? deciduous, } \\
\text { deep lesions, } \\
\text { no pulpitis }\end{array}$ & $\begin{array}{l}\text { only deepest layer decayed, } \\
\text { dentine left; capped with } \\
\mathrm{Ca}(\mathrm{OH})_{2} \text { or } \mathrm{ZnO} / \text { Eug or } \\
\text { amalgam; restored amalgam } \\
(\mathrm{n}=51)\end{array}$ & & $\begin{array}{l}25-206 \\
\text { days }\end{array}$ & $\begin{array}{l}\text { observation dentine } \\
\text { on re-entry, micro- } \\
\text { organisms }\end{array}$ & $\begin{array}{l}\text { initial samples of deep, soft } \\
\text { dentine, infected dentine harder } \\
\text { on re-entry with } \mathrm{Ca}(\mathrm{OH})_{2} \text { and } \\
\mathrm{ZnO} / \text { Eug but } \text { not } \text { with amal- } \\
\text { gam; } 3 / 8 \text { teeth exposed after } \\
\text { further caries removal with } \\
\text { amalgam; micro-organisms on } \\
\text { re-entry; } \mathrm{Ca}(\mathrm{OH})_{2} \text { teeth } 61.4 \% \\
\text { sterile; } \mathrm{ZnO} / \mathrm{Eug} \text { teeth } 81.8 \% \\
\text { sterile; amalgam teeth } 0 \% \\
\text { sterile but numbers of organisms } \\
\text { reduced }\end{array}$ \\
\hline $\begin{array}{l}\text { Kerkhove et al. } \\
\text { [1967] }\end{array}$ & $\begin{array}{l}\text { deciduous and } \\
\text { permanent, } \\
\text { deep lesions }\end{array}$ & $\begin{array}{l}\text { only deepest layer decayed, } \\
\text { dentine left; } 41 \text { teeth } \mathrm{Ca}(\mathrm{OH})_{2} \\
\text { and amalgam, } 35 \text { teeth } \mathrm{ZnO} / \\
\text { Eug and amalgam }\end{array}$ & & $\begin{array}{l}3-12 \\
\text { months }\end{array}$ & $\begin{array}{l}\text { observation of dentine } \\
\text { on re-entry, radio- } \\
\text { opacity relative to } \\
\text { control area assessed } \\
\text { visually and densi- } \\
\text { tometrically }\end{array}$ & $\begin{array}{l}92 \% \text { clinical success; on re- } \\
\text { entry dentine dry, hard, } \\
\text { brownish yellow; increased } \\
\text { radio-opacity; very slight time } \\
\text { but not material dependant }\end{array}$ \\
\hline $\begin{array}{l}\text { Magnusson and } \\
\text { Sundell [1977] }\end{array}$ & $\begin{array}{l}\text { deciduous, } \\
\text { deep lesions, } \\
\text { no pulpitis }\end{array}$ & $\begin{array}{l}\text { partial excavation; calcium } \\
\text { hydroxide, zinc oxide and } \\
\text { eugenol cement; at re-entry all } \\
\text { soft carious dentine excavated } \\
(\mathrm{n}=55)\end{array}$ & $\begin{array}{l}\text { full excavation } \\
(\mathrm{n}=55)\end{array}$ & 4-6 weeks & $\begin{array}{l}\text { clinical observation, } \\
\text { observation dentine } \\
\text { on re-entry }\end{array}$ & $\begin{array}{l}15 \% \text { treatment group pulp } \\
\text { exposed, } 53 \% \text { control group } \\
\text { pulp exposed }\end{array}$ \\
\hline $\begin{array}{l}\text { Weerheijm et al. } \\
\text { [1993] }\end{array}$ & $\begin{array}{l}\text { permanent } \\
\text { molars, small } \\
\text { visible occlusal } \\
\text { lesions }\end{array}$ & $\begin{array}{l}\text { part of lesion opened to den- } \\
\text { tine; this filled glass ionomer } \\
\text { cement }(\mathrm{GIC}) \text {; remainder } \\
\text { sealed GIC; at re-entry all } \\
\text { caries removed and composite } \\
\text { placed }(\mathrm{n}=20)\end{array}$ & $\begin{array}{l}\text { as treatment but } \\
\text { Delton sealant } \\
\text { used }(n=4)\end{array}$ & 7 months & $\begin{array}{l}\text { clinical observation of } \\
\text { dentine on re-entry } \\
\text { micro-organisms }\end{array}$ & $\begin{array}{l}\text { poor retention GIC sealant, } \\
\text { micro-organisms } 100 \text { times } \\
\text { less in re-entry sample but still } \\
\text { found in } 90 \% \text { of second samples }\end{array}$ \\
\hline $\begin{array}{l}\text { Leskell et al. } \\
\text { [1996] }\end{array}$ & $\begin{array}{l}\text { permanent, } \\
\text { deep, no pulpitis }\end{array}$ & $\begin{array}{l}\text { bulk carious dentine exca- } \\
\text { vated; calcium hydroxide, } \\
\text { zinc oxide and eugenol } \\
\text { cement; at re-entry all soft } \\
\text { dentine removed, } \\
\text { excavators or burs } \\
(\mathrm{n}=57)\end{array}$ & $\begin{array}{l}\text { all soft caries re- } \\
\text { moved, } \mathrm{Ca}(\mathrm{OH})_{2} \text {, } \\
\mathrm{ZnO} / \mathrm{Eug} \text { cement, } \\
\text { then GIC } \\
\text { composite or } \\
\text { amalgam } \\
(\mathrm{n}=57)\end{array}$ & 8-24 weeks & clinical observation & $\begin{array}{l}17.5 \% \text { treatment group } \\
\text { exposed, } 40 \% \text { control group } \\
\text { exposed }\end{array}$ \\
\hline $\begin{array}{l}\text { Kreulen et al. } \\
\text { [1997] }\end{array}$ & $\begin{array}{l}\text { permanent } \\
\text { molars, occlusal } \\
\text { caries on } \\
\text { radiograph }\end{array}$ & $\begin{array}{l}\text { lesions opened to dentine, } \\
\text { filled resin modified glass } \\
\text { ionomer }(n=40)\end{array}$ & $\begin{array}{l}\text { as treatment but } \\
\text { filled amalgam } \\
(\mathrm{n}=40)\end{array}$ & 6 months & $\begin{array}{l}\text { clinical observation of } \\
\text { dentine on re-entry } \\
\text { micro-organisms }\end{array}$ & $\begin{array}{l}\text { dentine darker and harder on } \\
\text { re-entry; substantial decrease in } \\
\text { total viable count, mutans strep- } \\
\text { tococci and lactobacilli; more } \\
\text { reduction with resin modified } \\
\text { glass ionomer than amalgam }\end{array}$ \\
\hline $\begin{array}{l}\text { Weerheijm et al. } \\
\text { [1999] }\end{array}$ & $\begin{array}{l}\text { permanent } \\
\text { molars, occlusal } \\
\text { caries on } \\
\text { radiograph }\end{array}$ & $\begin{array}{l}\text { lesions opened to dentine, } \\
\text { filled resin modified glass } \\
\text { ionomer }(n=33)\end{array}$ & $\begin{array}{l}\text { as treatment but } \\
\text { filled amalgam } \\
(\mathrm{n}=33)\end{array}$ & 2 years & micro-organisms & $\begin{array}{l}25 \text { patients reviewed; substan- } \\
\text { tial decrease in total viable } \\
\text { count, mutans streptococci and } \\
\text { lactobacilli; more decrease in } \\
\text { glass ionomer than amalgam; } \\
\text { micro-organisms not cultured } \\
\text { in } 11 \text { out of } 50 \text { cases }\end{array}$ \\
\hline
\end{tabular}


Table 2 (continued)

\begin{tabular}{|c|c|c|c|c|c|c|}
\hline Study & $\begin{array}{l}\text { Toothtype, } \\
\text { lesion depth }\end{array}$ & Treatment & Control & $\begin{array}{l}\text { Time to } \\
\text { re-entry }\end{array}$ & $\begin{array}{l}\text { Indication of carious } \\
\text { activity }\end{array}$ & Result and conclusion \\
\hline $\begin{array}{l}\text { Bjørndal et al. } \\
\text { [1997] }\end{array}$ & $\begin{array}{l}\text { permanent teeth, } \\
\text { no pulpitis, deep } \\
\text { lesions }\end{array}$ & $\begin{array}{l}\text { peripheral excavation and } \\
\text { excavation 'cariogenic } \\
\text { biomass' and superficial } \\
\text { demineralized dentine; } \\
\text { calcium hydroxide and } \\
\text { temporary filling; at re-entry, } \\
\text { complete excavation }(\mathrm{n}=31)\end{array}$ & & $\begin{array}{l}6-12 \\
\text { months }\end{array}$ & $\begin{array}{l}\text { clinical observation of } \\
\text { dentine on re-entry; } \\
\text { micro-organisms }\end{array}$ & $\begin{array}{l}\text { no pulpal exposures at final } \\
\text { excavation; at re-entry dentine } \\
\text { darker, harder, dryer; substantial } \\
\text { reduction in colony-forming } \\
\text { units - not time-dependent }\end{array}$ \\
\hline $\begin{array}{l}\text { Bjørndal and } \\
\text { Thylstrup } \\
{[1998]}\end{array}$ & $\begin{array}{l}\text { permanent teeth, } \\
\text { no pulpitis, deep } \\
\text { lesions }\end{array}$ & $\begin{array}{l}\text { peripheral excavation and } \\
\text { excavation 'cariogenic } \\
\text { biomass' and superficial } \\
\text { demineralized dentine; } \\
\text { calcium hydroxide and } \\
\text { temporary restoration } \\
(\mathrm{n}=94)\end{array}$ & & 2-9 months & $\begin{array}{l}\text { clinical observation of } \\
\text { dentine on re-entry; } \\
\text { follow up clinical and } \\
\text { radiographic } \\
\text { examination } 1 \text { year } \\
\text { after final restoration }\end{array}$ & $\begin{array}{l}\text { dentine harder and darker on re- } \\
\text { entry; } 5 \text { exposures on final } \\
\text { excavation ( } 2 \text { sensitive to pres- } \\
\text { sure, } 2 \text { inadequate seal): } 88 \text { cases } \\
\text { symptomless at } 1 \text { year; } 1 \text { case } \\
\text { lost temporarily and needed root } \\
\text { treatment }\end{array}$ \\
\hline $\begin{array}{l}\text { Bjørndal and } \\
\text { Larsen [2000] }\end{array}$ & $\begin{array}{l}\text { permanent teeth, } \\
\text { no pulpitis, deep } \\
\text { lesions }\end{array}$ & $\begin{array}{l}\text { as above }+ \text { microbiological } \\
\text { sampling }(n=9)\end{array}$ & & $4-6$ months & $\begin{array}{l}\text { clinical observation of } \\
\text { dentine on re-entry; } \\
\text { micro-organisms }\end{array}$ & $\begin{array}{l}\text { dentine harder and darker on re- } \\
\text { entry; colony-forming units and } \\
\text { proportion lactobacilli substan- } \\
\text { tially reduced; gram-negative } \\
\text { rods declined; flora dominated } \\
\text { by Actinomyces naeslundii and } \\
\text { various streptococci }\end{array}$ \\
\hline $\begin{array}{l}\text { Maltz et al. } \\
\text { [2002] }\end{array}$ & $\begin{array}{l}\text { permanent teeth, } \\
\text { no pulpitis, deep } \\
\text { lesions }\end{array}$ & $\begin{array}{l}\text { cavity walls made hard; } \\
\text { incomplete caries removal } \\
\text { pulpally; calcium hydroxide } \\
\text { and zinc oxide and eugenol } \\
\text { cement }\end{array}$ & & 6-7 months & $\begin{array}{l}\text { clinical observation of } \\
\text { dentine before and } \\
\text { after re-entry; radio- } \\
\text { graphic examination; } \\
\text { microorganisms }\end{array}$ & $\begin{array}{l}\text { dentine dryer, harder, darker on } \\
\text { re-entry; increase in radio-opaci- } \\
\text { ty during study period; bacterial } \\
\text { counts decreased significantly }\end{array}$ \\
\hline
\end{tabular}

Table 2 gives a chronological overview of stepwise excavation studies. The majority of these studies have no control. Most have been done on permanent teeth with deep lesions. The amount of carious dentine removed at the initial excavation varies from access to caries only, to removing the bulk of the carious dentine.

The restorative materials are also very variable. They include calcium hydroxide, zinc oxide and eugenol, amalgam, glass ionomer cement and composite resin. Times to re-entry are also very variable, the shortest being 3 weeks, the longest 2 years.

Caries activity has been assessed clinically, radiographically and often by microbiological examination at initial entry and on re-entry. With such differing methodologies, a systematic review is not possible but some themes emerge. (1) The clinical success rate appears high. Exposure is usually avoided using the stepwise technique and symptoms rarely arise between excavations. Control lesions are often exposed by conventional excavation. (2) Some studies report the dentine is altered on re-entry, being dryer, harder and darker. (3) Microbiological monitoring indicates substantial reductions in cultivable flora.
Some teeth appear sterile, but in most some micro-organisms survive. Two studies [Bjørndal and Larsen, 2000; Maltz et al., 2002] suggest that the cultivable flora is altered on re-entry to a less cariogenic flora. (4) There is a possibility that there may be an effect from the dental material on the outcome, but very few studies have addressed this in a controlled manner.

\section{Why Re-Enter?}

The studies in table 2 seem to show that the depth of the first excavation is not relevant to the level of infection of the soft, dry dentine that is found on re-entry. The final excavation allows the dentist to be sure there is no exposure and removes the remaining infected dentine. The logic here is that the carious process may continue, albeit slowly, in this infected tissue.

However, perhaps there is no need to re-enter and indeed this is the basis of the indirect pulp capping technique [Hilton and Summitt, 2000], although most of the demineralized tissues is removed in this procedure. In 
Table 3. Randomized controlled clinical trials of 'complete' versus 'incomplete' caries removal

\begin{tabular}{|c|c|c|c|c|c|}
\hline Study & $\begin{array}{l}\text { Tooth type, } \\
\text { lesion depth }\end{array}$ & Treatment & Control & $\begin{array}{l}\text { Observation } \\
\text { period }\end{array}$ & Results and conclusions \\
\hline $\begin{array}{l}\text { Magnusson and Sundell } \\
\text { [1977] }\end{array}$ & $\begin{array}{l}\text { deciduous, deep but } \\
\text { no pulpitis }\end{array}$ & $\begin{array}{l}\text { cavity washed microbioci- } \\
\text { dal solution; partial exca- } \\
\text { vation, calcium hydroxide, } \\
\text { zinc oxide and eugenol ce- } \\
\text { ment; at re-entry, all soft } \\
\text { carious dentine excavated } \\
(\mathrm{n}=55)\end{array}$ & $\begin{array}{l}\text { all softened dentine } \\
\text { excavated regardless } \\
\text { of risk of exposure } \\
(\mathrm{n}=55)\end{array}$ & $\begin{array}{l}\text { re-entry: } 4-6 \text { weeks } \\
\text { in treatment group }\end{array}$ & $\begin{array}{l}\text { treatment: } 2 \text { cases pulpitis } \\
\text { between visits, dentine } \\
\text { 'altered' on re-entry; } 15 \% \\
\text { pulps exposed; control: } 53 \% \\
\text { pulps exposed }\end{array}$ \\
\hline Leskell et al. [1996] & $\begin{array}{l}\text { permanent, deep but } \\
\text { no pulpitis }\end{array}$ & $\begin{array}{l}\text { bulk carious tissue exca- } \\
\text { vated, calcium hydroxide, } \\
\text { zinc oxide and eugenol } \\
\text { cement; at re-entry all soft } \\
\text { dentine removed with } \\
\text { excavator or burs }(n=57)\end{array}$ & $\begin{array}{l}\text { all softened dentine re- } \\
\text { moved; if no exposure, } \\
\text { calcium hydroxide, } \\
\text { zinc oxide and eugenol } \\
\text { cement, glass ionomer } \\
\text { cement; in some teeth } \\
\text { composite or amalgam } \\
\text { on top of this }(n=70)\end{array}$ & $\begin{array}{l}\text { re-entry: } 8-24 \text { weeks } \\
\text { in treatment group }\end{array}$ & $\begin{array}{l}\text { treatment: } 17.5 \% \text { pulps } \\
\text { exposed; easy to distinguish } \\
\text { 'soft' and 'hard' dentine on } \\
\text { re-entry; control: } 40 \% \text { pulps } \\
\text { exposed }\end{array}$ \\
\hline $\begin{array}{l}\text { Mertz-Fairhurst et al. } \\
\text { [1998] }\end{array}$ & $\begin{array}{l}\text { permanent; occlusal } \\
\text { lesions no deeper than } \\
\text { halfway into dentine on } \\
\text { radiograph }\end{array}$ & $\begin{array}{l}\text { DEJ not made caries free; } \\
\text { moist, soft, infected den- } \\
\text { tine left at DEJ and over } \\
\text { pulp; restored bonded, } \\
\text { sealed, composite } \\
(\mathrm{n}=156)\end{array}$ & $\begin{array}{l}\text { complete caries } \\
\text { removal; amalgam }+ \\
\text { sealant group }(\mathrm{n}=77) ; \\
\text { conventional amalgam } \\
\text { group }(\mathrm{n}=79)\end{array}$ & $\begin{array}{l}\text { no re-entry; } \\
\text { 10-year follow-up }\end{array}$ & $\begin{array}{l}\text { no exposure during caries } \\
\text { removal; treatment: } 85 \text { teeth } \\
\text { reviewed at } 10 \text { years, caries } \\
\text { apparently arrested, } 1 \text { lesion } \\
\text { 'caved in'; control: some } \\
\text { conventional amalgam rest } \\
\text { failed with new caries at } \\
\text { margin }\end{array}$ \\
\hline Ribeiro et al. [1999] & $\begin{array}{l}\text { deciduous, no pulpitis, } \\
\text { no exposure expected }\end{array}$ & $\begin{array}{l}\text { DEJ made caries free with } \\
\text { round bur but moist, soft, } \\
\text { infected dentine left over } \\
\text { pulp; restored dentine } \\
\text { bonding agent and } \\
\text { composite }(\mathrm{n}=24)\end{array}$ & $\begin{array}{l}\text { caries removal with } \\
\text { slow round bur guided } \\
\text { by caries dye; all dye } \\
\text { stained dentine } \\
\text { removed; restored } \\
\text { dentine bonding agent } \\
\text { and composite } \\
(\mathrm{n}=24)\end{array}$ & $\begin{array}{l}\text { no re-entry: followed } \\
\text { for } 1 \text { year; assessed } \\
\text { on radiograph and } \\
\text { histology }\end{array}$ & $\begin{array}{l}\text { treatment: all restorations } \\
\text { retained; excellent marginal } \\
\text { integrity after } 1 \text { year; on ra- } \\
\text { diograph: } 46 \% \text { regressed, } \\
25 \% \text { progressed, } 29 \% \text { un- } \\
\text { changed; adhesive system } \\
\text { formed altered hybrid layer } \\
\text { histologically; control: pul- } \\
\text { pal necrosis in } 1 \text { tooth, all } \\
\text { other restorations retained; } \\
\text { excellent marginal integrity, } \\
\text { adhesive system formed hy- } \\
\text { brid layer }\end{array}$ \\
\hline
\end{tabular}

stepwise excavation, on the other hand, soft, wet dentine is left in place. Is it now necessary to re-enter? After all, if the caries process is driven by the activity in the biofilm, the process should be arrested simply by sealing the cavity. The persistence of a few micro-organisms may be irrelevant. Perhaps they are just opportunistic squatters adapted to the new environment in which they find themselves.

\section{Randomized Controlled Clinical Trails}

Are there deleterious consequences after incomplete caries removal? Only randomized controlled clinical trials will answer this question and table 3 documents 4 such studies.

Caries Removal
Two of these selected deep lesions in deciduous [Magnusson and Sundell, 1977] or permanent [Leskell et al., 1996] teeth where exposure seemed likely following conventional caries removal. Both studies strongly support a stepwise approach (using calcium hydroxide after initial excavation) if pulp exposure is to be avoided. In these cases, conventional caries removal was deleterious; both studies re-entered.

The other two studies in table 3 selected less advanced lesions and did not re-enter to remove the remaining soft dentine in the treatment groups. Both studies sealed incompletely excavated cavities with dentine bonding agents and composite resins. The work of Ribeiro et al. [1999] on deciduous teeth concluded that the clinical performance of the restorations was not adversely affected by 
the incomplete caries removal after 1 year. The study by Mertz-Fairhurst et al. [1998] was remarkable for a 10-year follow-up of occlusal restorations placed over moist, soft, infected dentine left both at the enamel-dentine junction and over the pulp. Lesion progression was arrested and there were no more clinical failures in this group than in control groups with conventional caries removal.

\section{What Does the Evidence Tell Us about Our Current Operative Approach?}

This review makes uncomfortable reading for those of us teaching operative dentistry. There is no clear evidence that it is deleterious to leave infected dentine, even if it is soft and wet, prior to sealing the cavity. Indeed, this cautious approach may be preferable to vigorous excavation because fewer pulps will be exposed and sealing the dentine from the oral environment encourages arrest of lesion progression. The reparative processes of tubular sclerosis and tertiary dentine are encouraged, thus reducing the permeability of the remaining dentine. The residual micro-organisms are now in a very different environment. They are entombed by the seal of the restoration on one side and the reduced permeability of the remaining dentine on the other. The apparent irrelevance of the infected dentine is biologically logical if it is accepted that the caries process is driven by the biofilm and its reflection is the lesion in the dental hard tissues.

\section{Further Research}

One of the most intriguing aspects of this review is the fate of the residual micro-organisms. How do they survive? Is their survival time dependant? Do they change, either phenotypically or genotypically? Do they continue to demineralize the dentine, albeit very slowly? How does the pulp react to their presence in the short and long terms? In view of the numerous studies that show the pulp can be compromised by leakage of bacteria around restorations [Bergenholtz et al., 1982], it is remarkable that their presence does not result in pulpitis and pulp death. It is probably highly relevant that the studies relating bacterial leakage around restorations to pulp pathology are done on caries-free teeth. Thus, cavity preparation will open up millions of tubules, each one a pathway to the pulp. There is a dearth of research that relates the activity of a carious lesion to the histological changes in the underlying pulp. Is it really necessary to extract a tooth to examine pulpal pathology? There seems a need to find a way of monitoring what is going on in vivo.

The stepwise excavation studies in table 2 show many disparate methodologies. Randomized, controlled clinical trials should be designed to compare: the results of the stepwise technique in shallow and deep lesions; superficial caries removal with a deeper excavation; the relevance of the medicament (e.g. calcium hydroxide, zinc oxide and eugenol) and the filling material (amalgam, composite, glass ionomer cement) to the outcome, and the relevance of the time before re-entry to the clinical and microbiological outcome. In addition, this methodology might examine techniques designed to kill bacteria in infected dentine such as ozone treatment [Baysan et al., 2000] photo-activated disinfection [Burns et al., 1995; Williams et al., 2003]. Would these techniques help, hinder or be irrelevant to the clinical outcome?

Further long-term, randomized, controlled clinical trails will be important, but those who have attempted such work must look at the 10-year results of Mertz-Fairhurst et al. [1998] with admiration. The problem in clinical trials is usually an unacceptable loss of patients, but they seemed able to recall many of their patients. Stable populations will be required for these essential long-term studies.

\section{References}

Anderson MH, Loesch WJ, Charbeneau GT: Bacteriologic study of a basic fuchsin caries-disclosing dye. J Prosthet Dent 1985;54:51-55.

Baelum V, Fejerskov O: Caries diagnosis: 'A mental resting place on the way to intervention'?; in Fejerskov O, Kidd EAM (eds): Dental Caries. London, Blackwell Munksgaard, 2003, pp 101110.
Baysan A, Whiley RA, Lynch E: Antimicrobial effect of a novel ozone-generating device on micro-organisms associated with primary root carious lesions in vitro. Caries Res 2000;34: 498-501.

Beighton D, Lynch E, Heath MR: A microbiological study of primary root-caries lesions with different treatment needs. J Dent Res 1993;72: 623-629.
Bergenholtz G, Cox CF, Loesch WJ, Syed SA: Bacterial leakage around dental restorations: Its effect on the pulp. J Oral Pathol 1982;11:439_ 450.

Bjørndal L: Dentin caries: Progression and clinical management. Oper Dent 2002;27:211-217.

Bjørndal L, Larsen T: Changes in the cultivable flora in deep carious lesions following a stepwise excavation procedure. Caries Res 2000;34: 502-508. 
Bjørndal L, Larsen T, Thylstrup A: A clinical and microbiological study of deep carious lesions during stepwise excavation using long treatment intervals. Caries Res 1997;31:411-417.

Bjørndal L, Mjör IA: Pulp-dentin biology in restorative dentistry. 4. Dental caries - Characteristics of lesions and pulpal reactions. Quintessence Int 2001;32:717-736.

Bjørndal L, Thylstrup A: A practice-based study of stepwise excavation of deep carious lesions in permanent teeth: A 1-year follow-up study. Community Dent Oral Epidemiol 1998;26: 122-128.

Black GV: Operative Dentistry. The Technical Procedures in Filling Teeth. Chicago, MedicoDental Publishing Co, 1908, vol 11.

Bodecker CF: Histologic evidence of the benefits of temporary fillings and successful pulp capping of deciduous teeth. J Am Dent Assoc 1938;25: 777-786.

Boston DW, Graver HT: Histological study of an acid red caries-disclosing dye. Oper Dent 1989 ; 14:186-192.

Burns T, Wilson M, Pearson GJ: Effect of dentine and collagen on the lethal photosensitization of Streptococcus mutans. Caries Res 1995;29: 192-197.

ten Cate JM, Featherstone JDB: Physicochemical aspects of fluoride-enamel interactions; in $\mathrm{Fe}$ jerskov O, Ekstrand J, Burt B (eds): Fluoride in Dentistry. Copenhagen, Munksgaard, 1996, pp 252-272.

Eidelman E, Finn SB, Koulourides T: Remineralisation of carious dentin treated with calcium hydroxide. J Child Dent 1965;32:218-225.

Fusayama T: Clinical guide for removing caries using a caries-detecting solution. Quintessence Int 1988;19:397-401.

Going RE, Loesch WJ, Grainger DA, Syed SA: The viability of microorganisms in carious lesions four years after covering with a fissure sealant. J Am Dent Assoc 1978;97:455-462.

Handelman SL, Leverett DH, Solomon ES, Brenner CM: Radiographic evaluation of the sealing of occlusal caries. Community Dent Oral Epidemiol 1981;9:256-259.

Handelman SL, Washburn F, Wopperer P: Twoyear report of sealant effect on bacteria in dental caries. J Am Dent Assoc 1976;93:967-970.

Hilton TJ, Summitt JB: Pulpal considerations; in Summitt JB, Robbins JW, Schwartz RS (eds): Operative Dentistry. Chicago, Quintessence Publishing Co, Inc, 2000, p 103.

Jensen ØE, Handelman SL: Effect of an autopolymerizing sealant on viability of microflora in occlusal dental caries. Scand J Dent Res 1980 88:382-388.
Jeronimus DJ, Till MJ, Sveen OB: Reduced viability of microorganisms under dental sealants. J Dent Child 1975;42:275-280

Kerkove BC, Herman SC, Klein AI, McDonald RE: A clinical and television densitometric evaluation of the indirect pulp capping technique. J Dent Child 1967;34:192-201.

Kidd EAM, Joyston-Bechal S, Beighton D: The use of a caries detector dye during cavity preparation: A microbiological assessment. Br Dent $\mathbf{J}$ 1993; 174:245-248

Kidd EAM, Joyston-Bechal S, Beighton D: Marginal ditching and staining as a predictor of secondary caries around amalgam restorations: A clinical and microbiological study. J Dent Res 1995;74:1206-1211.

Kidd EAM, Ricketts D, Beighton D: Criteria for caries removal at the enamel-dentine junction: A clinical and microbiological study. Br Dent J 1996; 180:287-291.

King JB, Crawford JJ, Lindahl RL: Indirect pulp capping: A bacteriologic study of deep carious dentine in human teeth. Oral Surg Oral Med Oral Pathol 1965;20:663-671.

Kreulen CM, de Soet JJ, Weerheijm KL, Van Amerongen WE: In vivo cariostatic effect of resin modified glass ionomer cement and amalgam on dentine. Caries Res 1997;31:384-389.

Lager A, Thornqvist E, Ericson D: Cultivable bacteria in dentine after caries excavation using rose-bur or carisolv. Caries Res 2003;37:206211.

Law DB, Lewis TM: The effect of calcium hydroxide on deep carious lesions. Oral Surg Oral Med Oral Pathol 1961;14:1130-1137.

Leskell E, Ridell K, Cvek M, Mejare I: Pulp exposure after stepwise versus direct complete excavation of deep carious lesions in young posterior permanent teeth. Endod Dent Traumatol 1996;12:192-196.

Leung RL, Loesche WJ, Charbeneau GT: Effect of Dycal on bacteria in deep carious lesions. J Am Dent Assoc 1980;100:193-197.

Magnusson BO, Sundell SO: Stepwise excavation of deep carious lesions in primary molars. J Int Assoc Dent Child 1977;8:36-40.

Maltz M, de Oliveira EF, Fontanella V, Bianchi R: A clinical, microbiologic, and radiographic study of deep caries lesions after incomplete caries removal. Quintessence Int 2002;33:151159

Massler M: Pulpal reactions to dental caries. Int Dent J 1967; 17:441-460.

Mertz-Fairhurst EJ, Curtis JW, Ergle JW, Rueggeberg FA, Adair SM: Ultraconservative and cariostatic sealed restorations. J Am Dent Assoc 1998;129:55-66.
Mertz-Fairhurst EJ, Schuster GS, Fairhurst CW: Arresting caries by sealants: Results of a clinical study. J Am Dent Assoc 1986;112:194198.

Mertz-Fairhurst EJ, Schuster GS, Williams JE, Fairhurst CW: Clinical progress of sealed and unsealed caries. 1. Depth changes and bacterial counts. J Prosthet Dent 1979a;42:521-526.

Mertz-Fairhurst EJ, Schuster GS, Williams JE, Fairhurst CW: Clinical progress of sealed and unsealed caries. 11. Standardized radiographs and clinical observations. J Prosthet Dent 1979b;42:633-637.

Nyvad B, Fejerskov O: Active root surface caries converted into inactive caries as a response to oral hygiene. Scand J Dent Res 1986;94:281284.

Nyvad B, Fejerskov O: An ultrastructural study of bacterial invasion and tissue breakdown in human experimental root surface caries. J Dent Res 1990;69:2218-2225.

Ribeiro CCC, Baratieri LN, Perdigao J, Baratieri NMM, Ritter AV: A clinical, radiographic, and scanning electron microscope evaluation of adhesive restorations on carious dentin in primary teeth. Quintessence Int 1999;30:591-599.

Schouboe T, Macdonald JB: Prolonged viability of organisms sealed in dentinal caries. Arch oral Biol 1962; 7:525-526.

Thylstrup A, Qvist V: Principal enamel and dentine reactions during caries progression; in Thylstrup A, Leach SA, Quist V (eds): Dentine and Dentine Reactions in the Oral Cavity. Oxford, IRL Press, 1986, pp 3-16.

Tomes J: A System of Dental Surgery. London, John Churchill, 1859, p 336.

Weerheijm KL, de Soet JJ, van Amerongen WE, de Graaff J: Sealing of occlusal caries lesions: An alternative for curative treatment. J Dent Child 1992;59:263-268.

Weerheijm KL, de Soet JJ, van Amerongen WE, de Graaff J: The effect of glass ionomer cement on carious dentine. Caries Res 1993;27:417-423.

Weerheijm KL, Kreulen CM, de Soet JJ, Groen HJ, van Amerongen WE: Bacterial counts in carious dentine under restorations: 2-year in vivo effects. Caries Res 1999;33:130-134.

Williams JA, Pearson GJ, Colles MJ, Wilson M: The effect of variable energy input from a novel light source on the photo-activated bactericidal action of toludine blue $\mathrm{O}$ on streptococcus mutans. Caries Res 2003;37:190-193.

Yip HK, Stevenson AG, Beely JA: The specificity of caries detector dyes in cavity preparation. $\mathrm{Br}$ Dent J 1994;176:417-421. 